\title{
The Law of the Peacemaker: The Role of Mediators in Peace Negotiations and Lawmaking
}

\author{
Cindy Daase
}

\section{Keywords}

Mediators, Diplomacy, Peace Negotiations

\section{Introduction}

In 1966 a new comic superhero had his debut: The Peacemaker, alias Christopher Smith, US diplomat and Special Envoy to the Geneva Arms Conference, a convinced pacifist who, as the subtitle announced, "Loves peace so much that he is ready to fight for it!' 1 He took up arms for peace in his Peacemaker identity whenever diplomacy ceased to work. In the $4^{\text {th }}$ issue he fought against a villain from the Balkans and his guerrilla troops $\left.\right|^{2}$ The Peacemaker, of course, successfully stopped this disturbance of world peace, by using one of his portable atomic bombs $3^{3}$

The conceptualisation of The Peacemaker superhero character in this 1960s comic is a telling example of the myth that has been constructed around some

\footnotetext{
M.A. (Research Associate). Leipzig Centre for the History and Culture of East Central Europe (GWZO). The author wants to thank John Barker, Mehrdad Payandeh, Christian Schliemann-Radbruch, the participants of the Roundtable with Anne Orford organised by the Wissenschaftskolleg zu Berlin, the participants of the SIASSI 2012 Workshop "Regulating the World Society: Law, Governance and the Quest for Global Justice" convened by Alfred C. Aman and Peer Zumbansen and, of course, the organisers and participants of the the Cambridge Journal of International and Comparative Law conference "Agents of Change: The Individual as a Participant in the Legal Process" for their comments on earlier drafts of this article. The author feels especially indebted to Patricia Hania and Anne Prahtel for their invaluable comments and support. Any mistakes or misconceptions are the author's own.

1 Referring to the cover of The Peacemaker, No. 1, 1967. The Peacemaker had his debut in The Fightin' 5, No. 40, 1966.

2 The Peacemaker, No. 4, 1967.

3 The Peacemaker comic book turned out to be rather unsuccessful and several attempts to revitalise this superhero in different series were crowned by very modest success.
} 


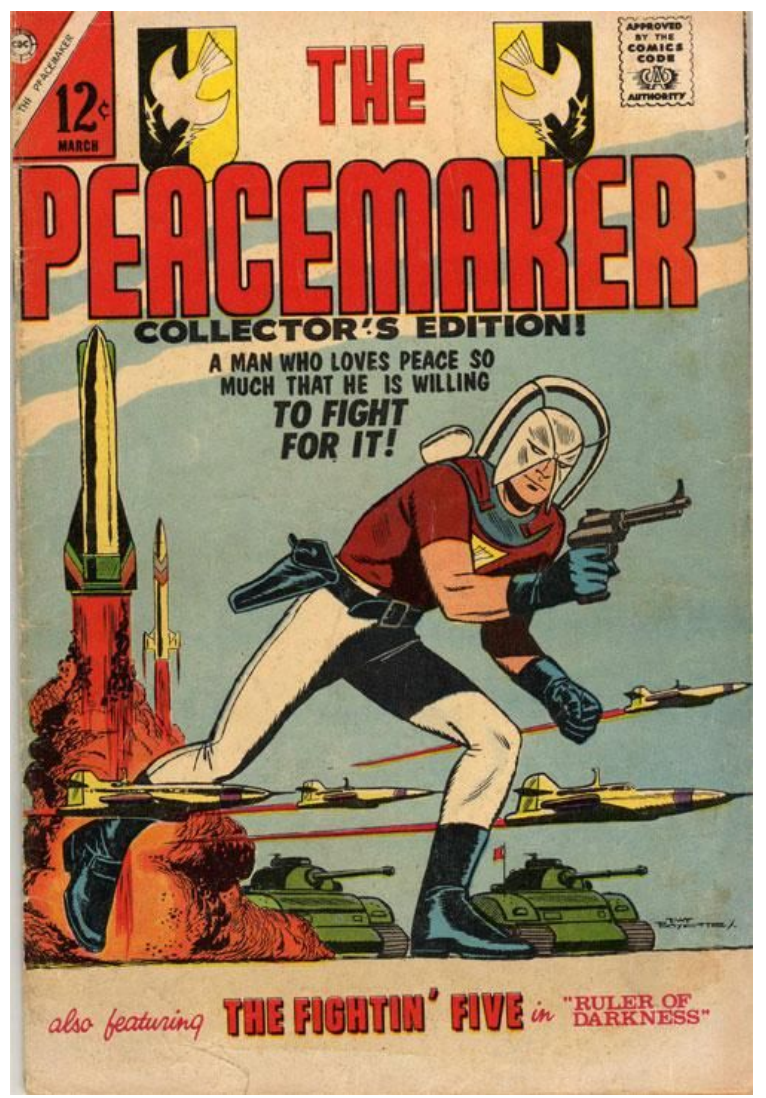

Figure 1: The Peacemaker No. 1, March 1967, Cover, by Pat Bovette Boyette. oDC Comics.

men (as they are mostly men) $4^{\sqrt[4]{ }}$ and their roles in mediation and peacemaking processes. The role of (charismatic) individual mediators in peace negotiations remains an object of mystification in public but also in academic discourses ${ }_{5}^{5}$ This especially holds true for US President's Special Envoy Richard Holbrooke and his role in the process leading to the Dayton Peace Agreement for Bosnia

4 Even Antonia Potter, a woman, dedicates only half a page to the lack of women in leading roles in the UN System and to the role some women have played in mediation processes including their special involvement in so-called track two mediations, in a book edited by a woman presenting six male mediators. A. Potter, 'In Search of the Textbook Mediator', in H. Martin (ed), Kings of Peace, Pawns of War: The untold story of peace-making (2006), 159, at 166.

5 See H. Martin (ed), Kings of Peace, Pawns of War: The untold story of peace-making (Continuum, 2006). See also infra Part II. 
and Herzegovina that will serve as a case study in this article 6

From a general perspective, peace processes can be considered as laboratories of lawmaking shaped by different (legal) actors. The role of mediation is usually analysed as one variation of an institutionalised form of third party involvement. The role of the individual mediator, however, is rarely the focus of analysis, while the traditional image of mediation, specifically the one promoted by the media, principally focuses on the enigmatic role of the charismatic individual expert-the peacemaker-shuttling from one place to another, trying to mediate between the parties and to negotiate an agreement to settle the conflict:7]

This article addresses the following questions: are mediators mere facilitators of a dialogue and negotiation process in a politically and legally set framework or are they-in their attempt not only to terminate a conflict but actively to create a sustainable peace process - in fact often dominating the process by procedurally and substantively imposing a peace agreement and predetermining the rules for the transition process? Which role is assigned to lawyers, law and lawmaking in mediation and peacemaking processes? For instance, does law set a framework or does it become an instrument or technique for the mediator/peacemaker to code the deal between the conflicting parties?

By taking Richard Holbrooke as a key example, the article seeks to describe and analyse the role of individual mediators in the negotiation and making of peace and peace agreements and their potential role in lawmaking in the grey zone between conflict and peace, as well as between the national and international sphere. At the same time, the author must remain aware of the danger of falling into the trap of mystifying Holbrooke's role as one of a superhero Peacemaker: the challenge is thus to describe and analyse the role of the individual mediator in peace and lawmaking processes by becoming immersed in, but not submerged by the "mystique" or "art-talk" around him.

Based on this outline, the article initially presents an overview of forms of mediation and functions of mediators in negotiation processes. As a leading example it then points to the mediation and negotiation processes in the conflicts following the dissolution of the Socialist Federal Republic of Yugoslavia (SFRY), most prominently the peace negotiation process for Bosnia and Herzegovina led by US Special Envoy Richard Holbrooke. Next, Holbrooke's role will be compared to the practice of the UN Secretary-General (SG) in conflict mediation based on his good offices, with a particular focus on the

\footnotetext{
6 See infra Part II, A.

7 For examples, see Martin, supra note 5 and infra Part II, III.
} 
role of Martti Ahtisaari as his Special Envoy in the Kosovo status negotiations from 2005 until 2007. Additionally, the article will also draw out processes of differentiation and professionalisation of peace mediation into so-called track one and track two processes. Against this background, the final question it addresses is whether a (professional) code of conduct is necessary or is in the process of being developed for peace mediators, especially when it comes to the growing number of private diplomacy and transnational mediation institutions.

\section{The Role of Mediators in Peace Negotiations}

Are there approaches and analytical frameworks that are designed to analyse, and in effect to "demystify", the role of mediators in peace and lawmaking processes? For a start, it is has to be acknowledged that negotiation and mediation often elude analysis due to their confidential character. Attempts to pursue for instance comprehensive discourse analysis are doomed to stagnate or fail due to the secrecy of talks and the lack of material to reconstruct them. A reason for this strict secrecy and exclusiveness, as well as avoidance of transparency and public participation, could be-next to dominantly political reasons-that negotiation outcomes, especially in form of peace agreements, could potentially be subject to some sort of judicial review ${ }^{8}$ Furthermore, it has been argued that it is not possible to develop patterns to analyse these processes and the role of actors involved on the basis that the observed differences in formats and functions would derive directly from the particular nature of the conflict situation and have their source in the respective characters of the intermediaries. The difficulties in generalising mediation processes and their participants is also closely related to the perception of mediation as a personal art of the mediator?

However, what does the existing body of social science literature say about mediation processes and the role of mediators in the making of peace and law?

8 A. D. Grimshaw, 'Research on the Discourse of International Negotiations: A Path to Understanding International Conflict Processes', (1992) 7 Sociological Forum, Special Issue: Needed Sociological Research on Issues of War and Peace 87, at 101 et seq.; and A. Wanis-St. John and D. Kew, 'Civil Society and Peace Negotiations: Confronting Exclusion', (2008) 13 International Negotiation 11, at 11, 13.

9 See for instance L. Kirchhoff, 'Linking Mediation and Transitional Justice', Paper presented at the International Conference 'Building a Future on Peace and Justice', Nuremberg, 25-7 June 2007, at 5-6 
Traditionally, mediation is understood as a political process in which parties to a violent conflict agree to the appointment of a third party to support them, impartially and without making binding decisions, in creating a negotiation process and reaching an agreement to end their conflict. Mediation, together with negotiation ${ }^{10}$ and good office ${ }^{11}$ is considered part of a set of political and diplomatic methods of dispute settlement that are conducted on invitation and without resorting to physical force or invoking the authority of the law ${ }^{12}$ This is also reflected in Article 33, Chapter VI on the Pacific Settlement of Disputes of the UN Charter 13

Furthermore, social science literature mostly categorises mediation processes as facilitative or interest-based mediation $\sqrt{14}$ formulative mediation $\sqrt{15}$ or

10 Negotiations can be defined as a process of joint decision-making in good faith conducted between the direct parties to a conflict. Negotiations do not necessarily need the involvement of a mediator. It has to be added that most negotiations in the course of intra-state conflicts are characterised by the asymmetry of the parties. See F. Vendrell, "The Role of Third Parties in the Negotiation and Implementation of Intrastate Agreements-An Experience-Based Approach to UN-Involvement in Intrastate Conflicts', in M. Boltjes (ed), Implementing Negotiated Agreements - The Real Challenge to Intrastate Peace (T.M.C. Asser Press, 2007), 193, at 199 et seq.; and Mediation Support Project (MSP), CSS, and Swisspeace, 'Unpacking the Mystery of Mediation in African Peace Processes', (2008), at 10, available at: <http://www.css.ethz.ch> [last accessed 5 February 2013].

11 See infra Part II, B.

12 Miller holds, "[t]he difference between mediation and negotiation is generally understood whether there are two parties or three. It is not always clear just how 'third' a third party is, even though many wish to paint an ideal portrait of the mediator as impartial, or as equally obliged to both sides, or as serving community interests judged to be moral, as well as in partial terms, less twisted by self-interest and passion than if the matters were left to unaided principle parties. Then too, the mediator's force is claimed to be mostly a moral force, aided by his rhetorical skills, or by his personal ability to cajole, flatter or threaten; for by definition he is without formal authority to impose a settlement. He is not a judge or an arbitrator..." See W. I. Miller, 'The Messenger', in G. Althoff (ed), Frieden Stiften, Vermittlung und Konfliktlösung vom Mittelalter bis heute (Wissenschaftliche Buchgesellschaft, 2010), 19, at 19. See also K. Beardsley, 'Agreement without Peace? International Mediation and Time Inconsistency', (2008) 52 American Journal of Political Science 723, at 724; Mediation Support Project (MSP), CSS, and Swisspeace, supra note 10, at 17; and F. Orrego Vicuña, 'Mediation' (2010) in MPEPIL (online edition), paras 1 et seq.

131945 Charter of the United Nations, 892 UNTS 119.

14 The facilitative mediator declines to make substantive contributions to the solution, but ensures a constructive dialogue between the disputants. Kleffner calls this "chairmanship". J. K. Kleffner, 'Peace Treaties' (2011) in MPEPIL (online edition), para 12.

15 Formulative mediation entails drafting agreements that are then presented and adapted by the parties. Thus, the mediator is required to enter the substance of the conflict and to make substantive contributions to the resolution process, including the development and proposal 
manipulative or directive mediation $\sqrt{16}$ The manipulative mediator has all the powers of the formulative mediator and, in addition, uses the position and leverage to manipulate the parties into an agreement. In effect, the manipulative mediator becomes a party to the negotiation process, making use of the capacity to add or subtract benefits to or from a certain solution. ${ }^{17}$ While facilitative and formulative mediation are still in line with the traditional characteristics of mediation, manipulative mediation influences the agreements decisively through setting incentives and disincentives. This includes setting the negotiation agenda, invoking the authority of law, even imposing solutions, and using the threat of sanctions and of the use of force in case of non-cooperation and non-compliance by the parties ${ }^{18}$ The category of manipulative mediation, as will be shown in the example of Richard Holbrooke, is highly relevant to describing and analysing the potential role of contemporary mediators.

However, while mediation processes are mostly analysed according to their form and function, the role of the individual mediator is to some extent still an object of mystification and attributed with a set of characteristics, which are not directly connected with or covered by the above introduced categorisations. The mediator is seen as a charismatic figure or artist who performs his art-conducting a mediation and peacemaking process - thereby using his personal charisma as well as the skills and tools at hand. To grasp this enigmatic role of the mediator, the involvement of US Special Envoy Richard Holbrooke in the complex setting of the dissolution of the SFRY will be taken as a leading example; it will then be compared to the role of the UN SG's good offices and of his Special Envoys in mediation processes, particularly the role of Martti Ahtisaari in the Kosovo status negotiations.

of new resolution options. At the same time the mediator is not in a position to push the conflict actors to endorse any particular outcome, or even to advocate a favoured outcome. Kleffner calls this "pro-active mediation”. Kleffner, supra note 14, para. 12.

16 Directive mediation is strongly controlling the process and the framework in which it takes place. See S. S. Gartner and J. Bercovitch, 'Overcoming Obstacles to Peace: The Contribution of Mediation to Short-Lived Conflict Settlements', (2006) 50 International Studies Quarterly 819 , at 823.

17 Kirchhoff, supra note 9, at 6.

18 Mediation Support Project (MSP), CSS, and Swisspeace, supra note 10, 10; and A. Herrberg, 'Perceptions of International Peace Mediation in the EU-A Needs Analysis', Initiative for Peacebuilding (2008), at 9. 


\subsection{The Architect of Dayton: Richard Holbrooke}

"We are inventing peace as we go", Richard Holbrooke said during his shuttle diplomacy between Belgrade, Sarajevo and Zagreb in $19955^{19}$ It can also be argued that Holbrooke and his team conducted a process that led to the invention or making of law as they went: The General Framework Agreement for Bosnia and Herzegovina and its Annexes, commonly known as the Dayton Agreement ${ }^{20}$

Richard Holbrooke, the "Architect of Dayton"21 had been involved in various peace negotiations throughout his long diplomatic career; his most famous appointment was to broker the peace agreement for Bosnia and Herzegovina as a Special Envoy of US President Bill Clinton. ${ }^{22}$ In his obituary President Barack Obama described Holbrooke, who died in 2010 at the age of 69, as "a true giant of American foreign policy," ${ }^{23}$ and concluded: "[T] he world is more secure because of the half century of patriotic service of Ambassador

19 Quoted in R. Cohen, 'After the Vultures: Holbrooke's Bosnia Peace Came Too Late, To End a War: From Sarajevo to Dayton-and Beyond by Richard Holbrooke (Review)', (1998) 77 Foreign Affairs 106, at 108. Holbrooke describing his shuttle diplomacy: R. Holbrooke, To End a War (The Modern Library, 1999), at 77 et seq.

201995 General Framework Agreement for Peace in Bosnia and Herzegovina with Annexes, with an introduction by P. C. Szasz, (1996) 35 ILM 75 et seq.

21 Cohen, supra note 19, at 109; D. L. Phillips, 'Comprehensive Peace in the Balkans: The Kosovo Question', (1996) 18 HRQ 821, at 828; 'Zum Tod von Richard Holbrooke-Voller Tatendrang und Ehrgeiz', Frankfurter Allgemeine Zeitung, 14 December 2010, <http://www.faz.net/ak tuell/politik/ausland/zum-tod-von-richard-holbrooke-voller-tatendrang-und-ehrgeiz-

11079239.html> [last accessed 4 August 2012]; and 'Richard Holbrooke, US Diplomat And Architect Of Dayton Peace Accords, Dies At 69', Radio Free Europe / Radio Liberty, 14 December 2010, <http://www.rferl.org/content/richard_holbrooke_dies_/2247460.html> [last accessed 4 August 2012].

22 During his long career in public service Holbrooke served inter alia as Foreign Service Officer in Vietnam, as Assistant Secretary of State for East Asian and Pacific Affairs during the Carter Administration. He was furthermore involved in the Cambodia negotiations and the failed attempts to settle the Kosovo conflict in 1998/1999. His last engagement as a Special Envoy for Afghanistan and Pakistan during the Obama Administration was highly disputed. See R. Jackson, 'International Engagement in War-Torn Countries', (2004) 10 Global Governance 21, at 32 and T. W. Crawford, 'Pivotal Deterrence and the Kosovo War: Why the Holbrooke Agreement Failed', (2001-2002) 116 Political Science Quarterly 499, at 511 et seq. On the special role of Special Envoys of US Presidents, see H. M. Wriston, 'The Special Envoy', (1960) 38 Foreign Affairs 219; and M. Fullilove, 'All the Presidents' Men-The Role of Special Envoys in US Foreign Policy', (2005) 84 Foreign Affairs 13, at 15.

${ }^{23}$ Quoted in E. Pilkington and A. Gabdatt, 'Richard Holbrooke, "giant of US foreign policy”, dies aged 69', The Guardian, 14 December 2010, <http://www.guardian.co.uk/world/2010/dec/14/richard-holbrooke-giant-of-diplomacy> [last accessed 13 August 2012]; M. Kelly, 'The Negotiator, Richard Holbrooke knows how 
Richard Holbrooke.' ${ }^{24}$ Foreign Policy, the journal Holbrooke once co-edited, proclaimed: "Holbrooke the Dove", while his widow, the writer Kati Marton, told a gathering of mourners that the best way to honour her late husband was "to press on with peace. 25

During and after the negotiation of the Dayton Agreement, Holbrooke's personality and controversial negotiation style-a sizeable ego and a tenacity and willingness to push hard for diplomatic results-won him both admiration and animosity and contributed to a certain mystification of his mediation skills ${ }^{26}$ His negotiation style earned him nicknames like the "Bulldozer" or the "Raging Bull", and the label of being "Washington's favourite last-ditch diplomat" 27 Holbrooke himself decisively contributed to this complex image with numerous interviews and speeches but most prominently with "To End a War", his memoir of the Bosnian peace process ${ }^{28}$ With this book he fed the arguments of both his critics as well as his admirers and nourished the prejudice that diplomacy and peacemaking in the Balkans was a special art form 29 Based on his diaries, cables, interviews with companions and media reports, Holbrooke retraced the process from the five-nation Contact Group's efforts to reach a settlement from 1994, via a number of pre-negotiation agreements and a decisive ceasefire ${ }^{30}$ to the Dayton negotiations, and finally to the first

to bully and beguile-an excellent job qualification for brokering peace in the Balkans', The New Yorker, 6 November 1995, 81, at 84; and R. D. McFadden, 'Strong American Voice in Diplomacy and Crisis', The New York Times, 14 December 2010, <http://www.ny times.com/2010/12/14/world/14holbrooke.html> [last accessed 13 August 2012].

24 President Barak Obama's tribute from 14 December 2010 is available at <http://con tent.usatoday.com/communities/theoval/post/2010/12/obama-holbrooke-a-true-giant-offoreign-policy/1\#.T4nb4loufgG> [last accessed 13 August 2012]. See also the memorial page of the US State Department: <http://www.state.gov/s/special_rep_afghanistan_pakistan /c40884.htm > [last accessed 13 August 2012] and of The American Academy in Berlin, which was founded by Richard Holbrooke: <http://www.americanacademy.de/home/aboutus/holbrooke-memorial> [last accessed 13 August 2012].

25 R. Ratnesar, 'Holbrooke's Legacy: The Power of Limited War', Time Magazine, 3 January 2011, <http://www.time.com/time/world/article/0,8599,2040486,00.html> [last accessed 13 August 2012].

${ }^{26}$ See Kelly, supra note 24, at 82, 84 .

27 Pilkington and Gabdatt, supra note 23.

${ }^{28}$ Kelly, supra note 23, 82; and R. Holbrooke, 'Why are we in Bosnia?-Annals of Diplomacy', The New Yorker, 18 May 1998, <http://www.newyorker.com/archive/1998/05 /18/1998_05_18_039_TNY_LIBRY_000015558> [last accessed 13 August 2012].

29 Holbrooke states in his book: "An aspect of the Balkan character was revealed anew: once enraged, these leaders needed outside supervision to stop themselves from self-destruction." Holbrooke, supra note 19, at 165; and Cohen, supra note 19, at 107.

30 "The terms of the deal were dictated and drafted largely by the Americans. 'We wrote the 
shaky steps of implementing the Agreement in 1996/1997. His accounts leave absolutely no doubt that he had created and wanted the job of negotiator and that he saw himself in that role, which should not necessarily be seen as synonymous with that of an impartial mediator ${ }^{31}$

In the eyes of some reviewers, "To End a War" tells the story of a passionate US public servant driven by American values struggling for peace in Bosnia: ${ }^{32}$ in the eyes of others it is an irritating egocentric account of the search for peace in the Balkans that, nevertheless, no student of the region and conflict mediation could afford to ignore ${ }^{33}$ In any case, Holbrooke's personal memories and the later released report and collection of documents on the Dayton negotiations of the State Department give an invaluable account of the negotiation process ${ }^{34}$ They illustrate the US's approach to use the threat of the use of force and the actual use of force by NATO to move the negotiation process along, most evident in Holbrooke's instigation: "Give us bombs for peace" It was also the use of force that attracted the most criticism 36 In

document', Holbrooke said flatly. But Holbrooke was careful to package the agreement in a tissue of niceties which would preserve the myth that the document had been a Serbian proposal with the Americans acting merely as its conveyor, and which would give Holbrooke, and his colleagues a very short arm's-length distance from the distasteful reality of having negotiated with criminals." Kelly, supra note 23, at 86 . Holbrooke himself considered negotiations as improvisations within the framework of the general goal. His plan was to create a series of agreements, in a high frequency of meetings to narrow the space to manoeuvre for the parties, to create a momentum for peace, and to bring the three Presidents together. This meant step-by-step negotiations, then writing the results down and making them public, thereby locking the parties and then returning to the negotiation table to address other still-open issues. Holbrooke pointed out that the disagreements on substance were less often the crucial point than those on procedures and protocol. At the same time he was aware that all the parties, including himself, were sitting at two tables: the peace negotiation table and a second one at home. See Holbrooke, supra note 19, at 111, 117, 131, 175.

31 "I would be interested in becoming the American negotiator for that problem, a position that did not exist in the Bush Administration." Holbrooke, supra note 19, at 43.

32 Cohen, supra note 19, at 107.

33 J. M. Sharp, 'To End a War by Richard Holbrooke', (1998) 74 International Affairs 919, at 920-1; and Cohen, supra note 19, at 107.

34 'The Road to Dayton, US Diplomacy and the Bosnia Peace Process, MayDecember 1995, US Department of State, Dayton History Project, May 1997 (declassified, available since 2003), The National Security Archive, <http://www.gwu.edu/ nsarchiv/NSAEBB/NSAEBB171/index.htm\#study> [last accessed 13 August 2012].

35 Holbrooke, supra note 2, at 32.

36 For example: "American negotiators had been obliged to waltz around the morally troubling issues of negotiating with war criminals and of linking diplomatic aims to the bombing of people with whom the United States was not at war." Kelly, supra note 23, at 86. 
his memoir, Holbrooke highlighted his conviction in the importance of the successful Croatian offensive as well as the NATO airstrikes, and the connection between them and the success of his negotiations. ${ }^{37}$ It is not surprising that an observer like Michael Kelly found: "To a considerable degree, what has been accomplished reflects the will and the nature of one man" 38 Kelly admits that the surrounding conditions played into Holbrooke's and his team's hands ${ }^{39}$ nevertheless, for him "the single force most responsible for driving the negotiations onward has been the ego of Richard Holbrooke" ${ }^{40}$ He continues: "For Holbrooke.... the Balkan mission is the Kissingerian role of a lifetime that has been spent in the pursuit of power and attention. He has played this role-the superdiplomat-in the central crisis of the age-in a manner that anyone who has ever known him would instantly recognize as classical Holbrookean. 41

But what makes the process that led to the Dayton Agreement and the Agreement itself a "classical Holbrookean"? For Kelly, it is Holbrooke yelling and cursing at Presidents and Foreign Ministers, negotiating agreements at all costs and being the last man standing at two o'clock in the morning ${ }^{42}$ Also, members of Holbrooke's mediation team ${ }^{43}$ contributed to the fixation on, and mystification of, the supermediator: James Pardew, then Director of the Balkan Task Force at the Department of Defence, stated in front of the media that it was Holbrooke's "conniving, playacting, seizing opportunity by instinct" that contributed decisively to the success of the negotiations. ${ }^{44}$ Brigadier General Donald L. Kerrick, then Director of the National Military Intelligence Collection Center, described with a certain admiration how Holbrooke even manipulated his team and placed them on the stage of what he considered the

37 See Holbrooke, supra note 19, at 86, 119, 199 et seq.

38 Kelly, supra note 23, at 81.

39 Namely, inter alia NATO's willingness to support US diplomacy by using force against the Serbs, the election of a new French government and the success of Croatian troops on the battlefield.

40 Kelly, supra note 23, at 81 .

41 Ibid.

42 Ibid.

43 Holbrooke's team consisted of General Wesley Clark; General Don Kerrick; the international lawyer Robert Owen; Chris Hill, Director of the Office of South-Central European Affairs, US Department of State (1994-1996); James Pardew, Director of the Balkan Task Force, Department of Defence (1995-1997); and Rosemarie Pauli, Department of State and Executive Assistant to Richard Holbrooke (1993-1996). Holbrooke also described the necessary character of negotiators and team members. See Holbrooke, supra note 19, at 10, 30 et seq., 44, 83, 377 et seq.

${ }^{44}$ Quoted in Kelly, supra note 23, at 88. 
theatre of negotiations ${ }^{45}$ Later, the renowned historian Fritz Stern even went so far as to say: "If Only Holbrooke Had Been in the Balkans in 1914", outlining how Holbrooke would have potentially prevented the outbreak of the First World War in summer 1914 46

When it came to the members of his negotiation team, Holbrooke pointed to the critical importance of having a skilled legal expert on board ${ }^{47}$ describing the appointment of Robert Owen as follows:

Christopher (Warren Christopher Secretary of State 1993-1997) noted that we lacked the legal expertise that would be essential if the negotiations got serious. He suggested adding to the team Robert Owen, a distinguished Washington lawyer. Bob Owen... had served, as the Legal Advisor to the State Department during the Carter Administration, was calm, witty, and always cheerfully ready for the most demanding tasks ... Christopher's inspired idea gave our team something it was to need continually: an experienced and wise international lawyer ${ }^{48}$

When Richard Holbrooke and his team started their work in August 1995, Holbrooke adopted previously drawn-up plans for a territorial division of Bosnia between a Bosnian-Croat Federation and an autonomous Serb entity. Instead of directly negotiating with the Bosnian Serb leadership, Holbrooke treated Slobodan Milosevic, then President of Serbia, as their proxy ${ }^{49}$ Hence, Milosevic was placed at the negotiation table and became, at the initiative of

${ }_{45}$ Ibid.

${ }^{46}$ F. Stern, 'If Only Holbrooke Had Been in the Balkans in 1914', Spring 2011 No. 20, The Berlin Journal, A Magazine of the American Academy in Berlin, at 14.

47 Holbrooke, supra note 19 , at 80 .

${ }^{48}$ Holbrooke later also described the mutual admiration between the lawyers Owen and Milosevic. See Holbrooke, supra note 19, at 134. Robert Owen was inter alia involved in drafting the Constitution of Bosnia and Herzegovina. Ibid., at 80, 240 et seq.

${ }^{49}$ Many earlier negotiation efforts of both the USA and European States had dealt with the Bosnian Serbs as a separate entity. See Holbrooke, supra note 19, at 5. The agreement that made Milosevic a negotiator for the Bosnian Serbs was the so-called Patriarch Agreement. Holbrooke commenting on the agreement and the new perspective for negotiations created by it said: "[T]he Patriarch Agreement and the bombing had greatly strengthened our hand... I asked Owen to start drafting the outlines of an interim, or partial, agreement. We did not consult or inform Washington." Ibid., at 111. In relation to the role of the entities Republika Srpska and the Federation of Bosnia and Herzegovina, see P. Gaeta, 'Symposium: The Dayton Agreements: A Breakthrough for Peace and Justice?, The Dayton Agreements and International Law', (1996) 7 EJIL 147, at 148 et seq. 
Holbrooke, a direct and key negotiator for peace in Bosnia and Herzegovina 5 Thus, officially, the Republic of Croatia ${ }^{51}$ the Federal Republic of Yugoslavia (FRY)/Republic of Serbia 52 and the Republic of Bosnia-Herzegovina $(\mathrm{BiH})^{\sqrt{53}}$ negotiated the Dayton Peace Agreement. Observers, however, underline that, although in theory the US negotiation team did not recognise Mladic and Karadzic as legitimate representatives of the Bosnian Serbs, it had to interact with them on several occasions before the final negotiations at Dayton began ${ }^{54}$ The Dayton proximity talks, from 1 to 21 November $1995 \sqrt{55}$ were conducted nominally under the auspices of the Contact Group, but actually under strict US management, namely that of Richard Holbrooke, his close negotiation team and a broader circle of members of the public service and the government ${ }_{56}^{56}$ Behind the scenes "State Department teams worked in harried haste to build both a conference and a nation. The magnitude of the job was indicated by the teams' encompassing titles: Framework Agreement, Separation of Forces, Constitution, Elections, Implementation Force, Economic Reconstruction, Refugees and Human Assistance, Congressional Consultations, Police, Press, United Nations Actions.' ${ }^{77}$ The teams continued their work in Dayton, and the working groups' focus issues were mirrored in what later became the Annexes

${ }^{50}$ While Milosevic sometimes demonstrated his direct and effective control over the Bosnian Serb leaders, he pointed on other occasions to the fact that every decision reached had to be approved and implemented by the Bosnian Serb leadership. See Anonymous, 'Human Rights in Peace Negotiations', (1996) 18 HRQ 249, at 253. John Kornblum makes this into a story of the struggle between two men: Holbrooke and Milosevic. See J. C. Kornblum, 'The Gift of Conviction, A former US ambassador to Germany on the enormous achievements of his successor', Spring 2011 No. 20, The Berlin Journal, A Magazine of the American Academy in Berlin, at 5.

51 In the case of Bosnian Croats, the close party links with the Republic of Croatia ensured that Croatian acceptance would translate into Bosnian Croat acceptance. The leader of the negotiation team was Croatian President Franjo Tuman.

52 The Bosnian Serb leadership had successfully undermined previous peace agreements, most notably the Vance-Owen Plan. The Bosnian Serb leadership had only conceded that Milosevic could negotiate on their behalf after considerable pressure was exerted. See F. Bieber, 'Power-sharing and International Intervention: Overcoming the Post-conflict Legacy in Bosnia and Herzegovina', in M. Weller and B. Metzger (eds), Settling Self-determination Disputes: Complex Power-sharing in Theory and Practice (Brill, 2008), 194, at 220; and Gaeta, supra note 49 , at 148 et seq.

53 The leader of the Bosnian negotiation team was President Alija Izetbegovic.

${ }^{54}$ Kelly, supra note 23, at 90.

55 "Proximity talks" as a technique: Holbrooke, supra note 19, at 205.

56 Holbrooke also made clear that he and his team were not acting on a UN-mandate. Holbrooke, supra note 19, at 153.

57 Kelly, supra note 23, at 90 . 
of the Framework Agreement 58 Thus, these teams essentially drafted the Agreement and its Annexes. Their influence can also been seen when Bosnian Foreign Minister Muhamed Sacirbey admitted to Holbrooke that the Bosnian team had no qualified international lawyers at hand to serve as legal experts during the negotiations. Although Robert Owen had provided them with a list of potential legal advisors beforehand, the Bosnians arrived in Dayton with only one "overworked and under-consulted international lawyer, Paul Williams" 59 This became a problem during the negotiations, for instance, when it came to Annex 1-A, Agreement on the Military Aspects of the Peace Settlement. On Holbrooke's initiative, the lawyer Robert Perle was invited to support the Bosnian negotiation team. Holbrooke recalled: "Perle took the first available plane to Dayton and ... started analyzing the military annex, whose bureaucratic language the Bosnians had been unable to decode... he closeted himself with the Bosnians, showing them the real, often hidden meaning of the jargon in Annex $1-\mathrm{A} " 60$ Perle's efforts resulted in a long list of changes and suggestions from the Bosnian side to the anger of some drafters of the US mediation team. Holbrooke commented on this situation in his memoir:

Most senior officials in Washington were still unhappy that Perle
was in Dayton. Donilon warned me that the Washington consen-
sus was to tell the Bosnians they had to accept Annex 1-A as orig-
inally written and reject all of their proposed changes. 'Tell Perle
to shove his goddamn changes up his ass', one angry Pentagon of-
ficial said when I warned him what to expect ... I replied 'We can't
reject them all, and some of them make sense.' (...) Clark, Kerrick,
Pardew, and I began a careful review of each suggestion, trying to

58 Holbrooke, supra note 19, at 240. For example: Annex 3-Elections, Annex 4-Constitution, Annex 10-Civilian Implementation of Peace Settlement, Annex 11-International Police Task Force, see 1995 General Framework Agreement for Peace in Bosnia and Herzegovina with Annexes, supra note 20.

59 Holbrooke, supra note 19, at 224. Paul R. Williams is an international lawyer and the cofounder as well as President of the Public International Law \& Policy Group (PILPG). Since 1995 this institution has provided pro bono legal assistance to states and governments involved in peace negotiations, drafting post-conflict constitutions, and prosecuting war criminal. For more information see $<\mathrm{http}: / /$ publicinternationallawandpolicy group.org/about/board/paul-r-williams/> [last accessed 8 August 2012]. For a reflection on pro bono work by international law firms, see M. Steinitz, 'Internationalized Pro Bono and a New Global Role for Lawyers in the 21st Century: Lessons from Nation-Building in Southern Sudan', (2009) 12 Yale Human Rights \& Development Law Journal 205.

${ }^{60}$ Holbrooke, supra note 19, at 253. 
decide how to deal with both the substance and the politics of his proposals 61

The final Dayton Agreement, which consists of a Framework Agreement and 12 Annexes, provided for the mutual recognition of the FRY and the Republic $\mathrm{BiH}$ (Article X). Furthermore, all the international forces and organs foreseen by the Agreements were not created by the parties or by any other instruments agreed upon in Dayton, but rather by later decisions of various international organisations, in particular the UN and NATO ${ }^{62}$ Remarkable is also Annex 4 , the Constitution. The Constitution is not the result of a classical process of constitution making and it is also no coincidence that its original language is English, as the main actors who led the drafting process were Richard Holbrooke, Carl Bildt and Robert Owen. ${ }^{63}$ Annex 4 was approved in separate declarations by the $\mathrm{BiH}$ Republic, the Federation and the Republika Srpska, and entered into force upon signature of the General Framework Agreement, thereby amending and superseding the $\mathrm{BiH}$ Republic's existing Constitution. ${ }^{64}$ The Constitution not only commits $\mathrm{BiH}$ to a comprehensive list of international human rights agreements; it is, beyond this, open to the direct application of international law, and it is even considered as being 'supervised' by international law 65 Moreover, in 2000 the Constitutional Court of $\mathrm{BiH}$, found:

Contrary to the constitutions of many other countries, the Constitution of $\mathrm{BiH}$ in Annex 4 to the Dayton Agreement is an integral part of an international agreement. Therefore, Article 31 of the $\mathrm{Vi}$ enna Convention of the Law on Treaties-providing for a general principle of international law which is, according to Article III.3 (b) of the Constitution of $\mathrm{BiH}$, an integral part of the legal system of

${ }_{61}$ Holbrooke, supra note 19, at 258. See also Gaeta, supra note 49 and E. M. Cousens, 'Making Peace in Bosnia Work', (1997) 30 Cornell Int. Law J. 789, at 789 et seq., 797 et seq.

${ }^{62}$ For example, the Implementation Forces (IFOR), the International Police Task Force (IPTF) and the High Representative. The Agreements only technically constitute the consent of the parties to have such forces and organs carry out specified functions, see 1995 General Framework Agreement for Peace in Bosnia and Herzegovina with Annexes, supra note 20, 78; Gaeta, supra note 49; and Cousens, supra note 61,

63 See Holbrooke, supra note 19, at 240; and Gaeta, supra note 49, at 160 et seq.

64 Art. XII, Annex 4, Dayton Agreement, see 1995 General Framework Agreement for Peace in Bosnia and Herzegovina with Annexes, supra note 20.

65 See inter alia Art. II, Annex 4 and Annex I to Annex 4 of the Dayton Agreement, 1995 General Framework Agreement for Peace in Bosnia and Herzegovina with Annexes, supra note 20, 79; Bieber, supra note 52, 230; Gaeta, supra note 49, at 161; and C. Bell, Peace Agreements and Human Rights (Oxford University Press, 2000), 68 et seq. 
Bosnia and Herzegovina and its Entities'-must be applied in the interpretation of all its provisions, including the Constitution of $\mathrm{BiH}^{66}$

An initiative to amend the Constitution in accordance with Article X, Annex 4 of the Dayton Agreement did not pass the Parliament in 2006 ${ }^{67}$

In a nutshell, the Dayton Agreement was an attempt to broaden traditional conceptions of peace agreements and ceasefires and to provide a blueprint using internationalised standards for the post-war reconstruction ${ }^{68}$ The peace agreement has been paradigmatic for an internationalised mediation and peace process in terms of the powers it vests in international institutions and personnel ${ }^{69}$ The role of the lawyers involved in this process seems to be one of gatekeepers and of technicians who create the code to transcribe and seal the deal.

In the end, the Dayton Agreement has been widely credited with ending a war, while both the negotiation process led by Richard Holbrooke and the resulting agreement have been severely criticised for failing to reduce substantially interethnic tensions as well as to guarantee an effective and responsible ownership by the people of $\mathrm{BiH}{ }^{70}$ In sum, Richard Holbrooke acted in the enigmatic and interpretative office of a Special Envoy of the US President, a position usually given to a person to negotiate with full authority of the President when it would be too sensitive for the US President or Secretary of State to act in person 11 In 1998, Bill Clinton sent Holbrooke, who was then

${ }^{66}$ Partial Decision III, Issue of the "Constituent Peoples", Constitutional Court of Bosnia and Herzegovina, Case U 5/98, 30 June and 1 July 2000, Official Gazette of Bosnia and Herzegovina No. 23/00, para. 19.

${ }^{67}$ Concerning the amendments, see European Commission for Democracy through Law (Venice Commission), Preliminary Opinion on the draft amendments to the Constitution of Bosnia and Herzegovina, Opinion 375/2006, CDL(2006)027, 7 April 2006; and D. Hays and J. Crosby, 'From Dayton to Brussels: Constitutional Preparations for Bosnia's EU Accession', United States Institute of Peace, Special Report 175, October 2006.

68 Bieber, supra note 52, at 219.

69 Bieber, supra note 52, at 214.

70 Kelly was convinced that Holbrooke "also led the United States into a tangle of accords and commitments whose ramifications, both practical and moral, no one-including the man who made them-fully understands." See Kelly, supra note 23, at 82 . Holbrooke himself said: "ON PAPER, DAYTON WAS A GOOD AGREEMENT... But countless peace agreements survived only in history books as case studies in failed expectations. The results of the international effort to implement Dayton would determine its true place in history. And the start was rocky." Holbrooke, supra note 19, at 335 . Holbrook also enumerated the flaws of the agreement. See ibid., at 363.

${ }^{71}$ Wriston, supra note 22; and Fullilove, supra note 22. 
US Ambassador to the UN, on another troubleshooting mission: the Kosovo crisis ${ }^{72}$ His attempts to negotiate an arrangement with Milosevic failed at this point in time, and observers attested Holbrooke a very flat learning curve in dealing with the charismatic Serbian President ${ }^{73}$

Seven years later another diplomat was sent out, this time as a Special Envoy of the SG, to negotiate the future status of Kosovo: Martti Ahtisaari. Arnault once held that the conflict between the creation of a negotiated settlement and current international legal standards is never as acute as when the UN serves as a mediator. This leads to the question which kind of institutionalised framework the UN and the SG offer for mediation and negotiation processes ${ }^{74}$

\subsection{The Secretary-General's Good Offices and Mediation}

Since the end of the Cold War, the SG and the UN have grappled with concepts to address so-called new and asymmetric conflicts. This has led to intensified discussions about already existing approaches, forms and standards of UN involvement, especially in intra-state conflicts and peace processes. Mediation is one of the means at the disposal of the SG to initiate and accompany peace

72 R. McFadden, 'Strong American Voice in Diplomacy and Crisis', The New York Times, 13 December 2010, <http://www.nytimes.com/2010/12/14/world/14holbrooke.html?page wanted $=$ all $>$ [last accessed 13 August 2012].

73 In 1998, on a flight to Belgrade, Holbrooke told Michael Ignatieff that diplomacy was not like chess, but more like jazz, a constant improvisation on a theme, and referring to the image of him acting as a free agent Holbrooke told Ignatieff: "People say I have no instructions... Actually, I have twelve pages of them here." Quoted in J. Jon Michaud, 'Richard Holbrooke in the New Yorker', The New Yorker, 14 December 2010, <http://www.newyorker.com/on line/blogs/backissues/2010/12/richard-holbrooke-in-the-new-yorker.html> [last accessed 13 August 2012].

74 J. Arnault, 'Good Agreement? Bad Agreement? An Implementation Perspective', Center of International Studies Princeton University (undated), at 21, <http://www.stanfo rd.edu/class/psych165/Arnault.doc> [last accessed 13 August 2012]; Arnault's statement was echoed by The UN Peacemaker database: "When the United Nations is called upon to mediate a resolution to a conflict, it means that the parties have accepted the United Nations Peacemaker to help and provide solutions to resolve the conflict. A United Nations mediation mandate grants authority to the Secretary-General or his Envoys to listen to the parties and to propose ideas and solutions. While the final outcome has to be agreed to by the parties, being a United Nations Mediator entails a much greater responsibility and involvement in the outcome of the conflict. A United Nations mediation mandate gives the parties the opportunity to avail themselves of the experience and best practices that the Organisation has gained in the field of conflict resolution.” The UN Peacemaker, <http://peacemaker.unlb.org/index1.php> [last accessed 13 August 2012]. 
processes ${ }^{75}$ In 2005, the UN World Summit agreed to strengthen both the SG's capacity to mediate disputes and the SG's good office ${ }^{76}$ Good office is commonly understood as the deployment of diplomatic means for the settlement of disputes through a modest form of third party involvement in which the third party encourages or supports the disputing parties to resume negotiations but does not actively take part in them ${ }^{77}$ This conceptual difference is in practice blurred, and it is often difficult to determine whether the third party has only brought the disputing parties together or whether it also actively assisted them in reaching a compromise - which would be the role of the mediator ${ }^{78}$ The SG's role in the mediation of inter- and intra-state conflicts can be inferred from the position of the SG envisioned by the UN Charter as one of the principle organs of the UN ${ }^{79}$ The SG, as a mediator, is equipped with the authority of his office. 80 During the last two decades, the SG was not able to exercise this function in person for every conflict. To address various conflict situations and issues at the same time, the SG began appointing more and more Special Envoys and Special Representatives ${ }^{81}$ There is no generally agreed definition of who, equipped with which mandate, is considered as a Special Envoy or Special

75 See inter alia 'Politically Speaking', (Winter 2007-2008) Bulletin of the United Nations Department of Political Affairs, 4 et seq.; and A more secure world: Our shared responsibility, Report of the High-level Panel on Threats, Challenges and Change, UN Doc. A/59/565, 2 December 2004. See also C. Bell, On the Law of Peace -Peace Agreements and the Lex Pacificatoria (Oxford University Press, 2008), at 66 et seq.

${ }^{76}$ United Nations, 2005 World Summit Outcome, UN Doc. GA/RES/60/1, 24 October 2005, para. 76; and T. Whitfield, 'Good offices and "groups of friends"', in S. Chesterman (ed), Secretary or General?, The UN Secretary-General in World Politics (Cambridge University Press, 2007), at 86.

77 For characteristics of good office and the role of mediators see also Arts. 3 and 4 of the Convention (I) For the Pacific Settlement of International Disputes (Hague I), 29 July 1899. See furthermore R. Lapidoth, 'Good Office' (2005) in MPEPIL (online edition), paras 1 et seq.

78 Interestingly enough the UN Charter mentions mediation but does not mention good office in its list of means for the pacific settlement of disputes in Art. 33. See also: Lapidoth, ibid., paras 2, 4, 6 et seq. (with examples).

79 I. Johnston, 'The Secretary-General as norm entrepreneur', in S. Chesterman (ed), Secretary or General?, The UN-Secretary General in World Politics (Cambridge University Press, 2007), 123 , at 131.

${ }^{80}$ See K. Göcke and H. von Mohr, 'United Nations, Secretary General' (2011) in MPEPIL (online edition), paras 25-6. For details of codes of conduct, see Declaration on the Prevention and Removal of Disputes and Situations Which May Threaten International Peace and Security and on the Role of the United Nations in this Field, UN Doc. GA/RES/43/51, 5 December 1988.

81 Since the 1990s, the number of Special Representatives has increased significantly. See H. Keller, 'Special Representative' (2008) in MPEPIL (online edition), para. 10; and Göcke and von Mohr, supra note 80, paras 47 et seq. On Special Envoys, see M. Payandeh, 'Special 
Representative-the terms are often used synonymously. However, there is the tendency to call someone a Special Representative if he/she is appointed on behalf of a collective body, for instance the Security Council (SC), and to speak of a Special Envoy when a person is chosen and appointed on the initiative of the $\mathrm{SG}^{82}$ The competence of the SG to appoint Special Envoys could be read into Articles $97-101$ of the UN Charter ${ }^{83}$ It is even argued that the authority of the SG to choose and appoint Special Envoys has developed into a rule of customary international law. This would have to derive from the practice and opinio iuris of the member states of the UN and should not be confused with practice of an office shaped by the individual SG ${ }^{84}$ More convincing is the finding that the appointment of Special Envoys seems to be a practice-adapted and well-tried mechanism of conflict mediation and settlement by the SG's office ${ }^{85}$

The most obvious advantage of the SG's involvement as a mediator, or the

Envoy' (2009) in MPEPIL (online edition), paras 1 et seq. For an interesting perspective on how SG Hammarskjöld shaped the SG's office, see A. Orford, International Authority and the Responsibility to Protect (Cambridge University Press, 2011), at 3 et seq., 49 et seq.

82 A distinction between different mandates of Special Envoys and Special Representatives can be found in a series of reports given by SG Boutros Boutros-Ghali to the General Assembly (GA) in which he distinguished: (1) Special Representatives in peacekeeping or observer missions based on a mandate by the SC, (2) Special Envoys who are supposed to assist the SG in the exercise of his good office and related functions, and (3) other high level positions in the UN system. According to this classification, a Special Representative is appointed by the SG on the request of the SC or the GA, whereas the appointment of a Special Envoy is based the SG's own initiative or on informal consultation between the SG and the GA and/or the SC. See Special Representatives, Envoys and Related Positions, Report of the Secretary-General, UN Doc. A/C.5/48/26, 15 November 1993, para. 12; Special Representatives, Envoys and Related Positions, Report of the Secretary-General, UN Doc. A/C.5/49/50, 8 December 1994, paras 5, 8 et seq.; and Special Representatives, Envoys and Related Positions, Report of the Secretary-General, UN Doc. A/C.5/50/72, 20 September 1996, paras 4-5. On the complicated relationship between the SG and the SC, see J. Cockayne and D. M. Malone, 'Relations with the Security Council', in S. Chesterman (ed), Secretarr of General?, The UN Secretary General in World Politics (Cambridge University Press, 2007), at 69-85, 70, 74. See also Orford, supra note 81, at 10 et seq.

83 See Reparations for Injuries Suffered in the Service of the United Nations, Advisory Opinion, ICJ Reports 1949, p. 174, at 182; Orford, supra note 81, at 10 et seq.; and Johnston, supra note 79, 131. In a number of cases, the SG takes initiative without any mandate as foreseen in Art. 98 and outside the scope of Art. 99 UN Charter. This is mostly the case in the context of quiet and preventive diplomacy. These initiatives are based on a case to case (sui generis) approach and there is no clear legal basis to be found in the UN Charter. See Göcke and von Mohr, supra note 80, paras 11 et seq., 18 et seq., 21 et seq; Payandeh, supra note 81, para. 8 et seq.; and Keller, supra note 81, para. 11.

84 Keller, supra note 81, para. 12.

85 Keller, supra note 81, para. 13. 
appointment of a Special Envoy like Martti Ahtisaari, is that the individual is purportedly acting under a personal mandate of the world's only global organisation with an assumed unparalleled legitimacy which provides a set of standards and a normative framework for mediation and negotiation processes ${ }^{86}$ In sum, the SG and the SG's Special Envoys face the challenge of acting as mediators on this basis, promoting global norms whilst retaining the freedom and leverage to shape and adapt their office to a particular situation, and sometimes contradicting local needs, as can also be demonstrated by the example of Noble Prize Laureate Martti Ahtisaari ${ }^{87}$

In 2005, the SG appointed former Finnish President Martti Ahtisaari as his Special Envoy to lead a process that was supposed to determine the status of Kosovo ${ }^{88}$ The beginning of the final status talks was conditional on meeting a set of internationally established benchmarks and standards ${ }^{89}$ This mediation is mostly perceived as a form of mandatory mediation due to a lack of other means for the parties to settle their dispute over Kosovo's political and legal status. Representatives from the Serbian government (including representatives of Kosovo Serbs), the Kosovo delegation (including opposition representatives) and the Contact Group ${ }^{90}$ began regular meetings in Vienna to reach a settlement. The parties met every few weeks to discuss draft agreements that had been prepared by Ahtisaari's mediation team. The task of UN Special

${ }^{86}$ Madeleine Albright, former US Ambassador to the UN and Secretary of State once said that the SG wears three hats: as super-negotiator, diplomat, and manager of the UN System. Concerning the SG's role in filling 'normative vacuums', see Q. Trinh, 'The bully pulpit', in S. Chesterman (ed), Secretary or General?, The UN Secretary General in World Politics (Cambridge University Press, 2007), at 102-20, 107 et seq., 116. See also: Johnston, supra note 79, at 138.

87 See the Norwegian Nobel Committee, <http://www.nobelprize.org/nobel_prizes/peace/lau reates/2008/press.html> [last accessed 13 August 2012].

88 'Kosovo: Annan to name veteran trouble-shooter Ahtisaari to lead status talks', UN News Centre, 1 November 2005, <http://www.un.org/apps/news/story.asp?NewsID=16433\&Cr=kosovo\&Crl> [last accessed 13 August 2012].

89 See Independent Commission on Kosovo, The Kosovo Report (Oxford University Press, 2000); also available as 'The Kosovo Report', Independent Commission on Kosovo, Executive Summery, 1 October 2000, <http://reliefweb.int/node/21913> [last accessed 13 August 2012]. See also R. Goldstone et al., 'International Law, Politics and the Future of Kosovo', (2008) 102 Proceedings of the Annual Meeting of the American Society of International Law 129, at 129.

90 Consisting of France, Germany, Italy, the Russian Federation, the UK, and the USA. During the final status negotiations, the Contact Group set an overall framework for the future status in January 2006: it contained three "no's", i.e. "no" return to the status Kosovo had until 1999, "no" union with any other country, and "no" partition, see 'Understanding conflicts and mediation: Case of Kosovo', University of Bologna, Working Papers, 31 July 2009, <http://foreignpolicy.it/adon.pl?act=doc\&doc=4777> [last accessed 13 August 2012]. 

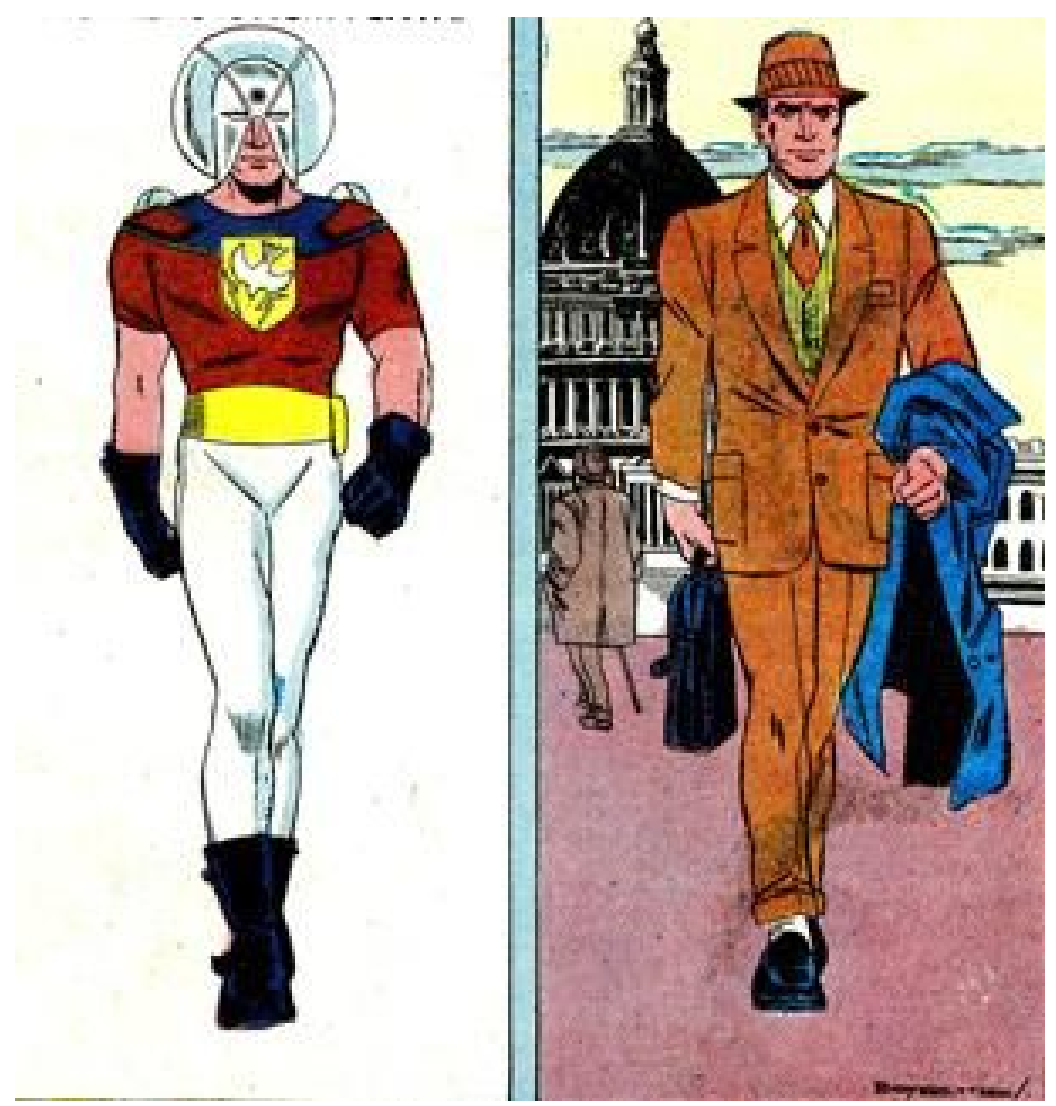

Figure 2: Debut of the Peacemaker in The Fightin' 5, No. 40, 1966. @DC Comics.

Envoy Ahtisaari was undeniably very difficult in terms of its political and legal dimensions. Additionally, the task of the Office of the Special Envoy of the Secretary-General of the United Nations for the future status process for Kosovo (UNOSEK ${ }^{\sqrt{1}}$ was not only to organise the schedule of negotiations but also to provide Special Envoy Ahtisaari with legal and political advice, inter alia to ensure that a proposed agreement would be in line with international law. Despite all efforts, the negotiation process stagnated in summer/autumn 2006. ${ }^{92}$ The Serbian side held that Ahtisaari was in fact mediating in favour of

91 Office of the Special Envoy of the Secretary-General of the United Nations for the future status process for Kosovo, <http://www.unosek.org/> [last accessed 13 August 2012].

92 The question of whether both parties negotiated in good faith was intensively discussed in written and oral statements during the Advisory Proceedings of the ICJ. See inter alia: Accordance with International Law of the Unilateral Declaration of Independence by the Provisional 
the representatives of Kosovo, whose goal was independence, a suspicion that was also strongly reflected in the media ${ }^{93}$ In the end, the question was whether Ahtisaari would be able to lead the status negotiations to an effective agreement between the parties or whether he had to redefine his office as a Special Envoy and mediator to find and provide a solution to the conflict. This made the mediator in effect the status maker.

In 2007, Martti Ahtisaari made recommendations regarding Kosovo to the Security Council in which he came up with a model solution: a supervised independence for Kosovo ${ }^{94}$ The so-called Ahtisaari Plan was endorsed by the SG but not taken up by the SC in a Chapter VII Resolution?5 The Ahtisaari Plan was later included in Kosovo's Declaration of Independence and can be considered as the foundation of Kosovo's supervised sovereignty; it also informed the constitution-making process and made its way inter alia into Article 143 of Kosovo's Constitution 96

In contrast to the mandatory mediation and solution finding performed during the Kosovo status negotiations, Ahtisaari, for whom "[p]eace is a question of will", ${ }^{77}$ underlined in his Nobel speech: "The task of the mediator is to help the parties to open difficult issues and nudge them forward in the peace process. The mediator's role combines those of a ship's pilot, consulting

Institutions of Self-Government of Kosovo, Order of 17 October 2008, ICJ Reports 2008, p. 409; Request for an advisory opinion of the International Court of Justice on whether the unilateral declaration of independence of Kosovo is in accordance with international law, UN Doc. A/63/L.2, 23 September 2008; and Accordance with International Law of the Unilateral Declaration of Independence in Respect of Kosovo, Advisory Opinion, 22 July 2010, General List No. 141.

93 'Serbian press mistrusts Kosovo plan', BBC News, 3 February 2007, <http://news.bbc.co .uk/2/hi/europe/6326947.stm> [last accessed 13 August 2012]; N. Wood, 'Serbs Criticize U.N. Mediator, Further Bogging Down Kosovo Talks', The New York Times, 2 September 2006, <http://www.nytimes.com/2006/09/02/world/europe/02kosovo.html> [last accessed 13 August 2012]; and A. Ivanji, 'Martti Ahtisaari's Compromise Proposal for the Kosovo', Eurotopics, March 2007, <http://www.eurotopics.net/en/home/presseschau/archiv/mag azin/politik-verteilerseite/kosovo-2008-03/debatte_kosovo_2007_03/> [last accessed 13 August 2012].

94 Taking up suggestions which were already made by the Independent Commission on Kosovo. See supra note 89; Report of the Special Envoy of the Secretary-General on Kosovo's future status, UN Doc. S/2007/168, 26 March 2007; and Report of the Special Envoy of the Secretary-General on Kosovo's future status, UN Doc. S/2007/168 Add.1, 26 March 2007.

95 Goldstone et al., supra note 89, at 129. UN Doc. SC Res 1244, 10 June 1999 is still in force.

96 Kosovo Declaration of Independence, 17 February 2008, Art. 12; Constitution of the Republic of Kosovo, 15 June 2008, Art. 143, Chapter XIII.

97 M. Ahtisaari, 'Nobel Lecture', Oslo 10 December 2008, <http://www.nobelprize.org/no bel_prizes/peace/laureates/2008/ahtisaari-lecture_en.html> [last accessed 13 August 2012]. 
medical doctor, midwife and teacher" 98 Ahtisaari admitted that there tends to be a strong focus on the person of the mediator and criticised this by stating: "With that we are disempowering the parties to the conflict and creating the wrong impression that peace comes from the outside. The only people that can make peace are the parties to the conflict, and just as they are responsible for the conflict and its consequences, so should they be given responsibility and recognition for the peace" 99 In the end, Ahtisaari found that "[e]ven though all eyes are often on the peace mediators, it is important to emphasise the role of the mediation teams and the other important actors outside the direct negotiation process itself.' 100 Ahtisaari, founder of the Crisis Management Initiative (CMI), an independent non-profit private diplomacy and mediation organisation, also critically reflected that mediation processes often exclusively focus on negotiations between elites, so called track one negotiations. ${ }^{101}$ In his conclusion, the Nobel Prize laureate pointed to the necessity of cooperation of all parties to a conflict and all actors who are involved in the peace process and to the need for expertise in conflict mediation and negotiation ${ }^{102}$ Moreover, Ahtisaari also pointed to the role of the $\mathrm{UN}$ as an institutionalised third party in peace processes while admitting, based on his own experiences, the constraints of UN peace mediations, especially due to the de facto divergences between the demanding assignments of UN mediation and the provision of adequate resources and political support ${ }^{103}$ This critique was recently underlined by former SG Kofi Annan, when he announced his resignation from his office as a Joint Special Envoy of the UN (Department for Political Affairs) and League of Arab States for the Syrian crisis ${ }^{104}$ Rumour has it that Lakhdar Brahimi, another experienced high-profile mediator, will be the next appointee to this extremely complicated position 105

\footnotetext{
98 Ibid.

99 Ibid.

${ }^{100}$ Ibid.

101 Ibid.

102 Ibid.

${ }^{103}$ Ibid.

${ }^{104}$ Kofi Annan Appointed Joint Special Envoy of United Nations, League of Arab States on Syrian Crisis, Secretary-General, UN Doc. SG/SM/14124, 23 February 2012; and 'Kofi Annan resigns as UN-Arab League Joint Special Envoy for Syrian crisis', UN News Centre, 2 August 2012, <http://www.un.org/apps/news/story.asp?NewsID=42609> [last accessed 4 August 2012].

${ }^{105}$ About Lakhdar Brahimi as a mediator, see for instance Martin, supra note 5, at 1-28.
} 


\subsection{Mediators: Architects or Artists of Peace Making?}

In his famous speech at the Reichstag in 1878, Otto von Bismarck offered himself as an honest broker for the Berlin Congress, as someone who would act less like an arbitrator and more as a facilitator of a deal between the parties. This offer determined the modern picture of the impartial third party, represented by a charismatic individual mediator with (allegedly) no stakes in the conflict and the results of the negotiation process. ${ }^{106}$ "War was the belligerents' concern it would end when it ended ... If there was peacemaking, it depended on the consent of the belligerents and the peacemaker. Even then, the peacemaker waited patiently for 'l'instant proprice' ", explains Michael Reisman with regard to the contrast between $19^{\text {th }}$ and early $20^{\text {th }}$ century versus contemporary third party involvement in peace processes ${ }^{107}$ The traditional role of a mediator was understood to be part of a political process in which parties to a violent conflict agree to the appointment of a third party to support them, impartially and without making binding decisions, to create a negotiation process and to reach an agreement to end the violent conflict. The conflict parties set the constraints and goals in this process.

As shown above, contemporary mediation does not necessarily wait anymore for the clear victory or capitulation of one party or a declared stalemate between the belligerents ${ }^{108}$ The negotiation of the formal termination of inter- and intra-state conflicts and the following peace process are no longer left to the parties alone but often become guided, authoritative, international transactions ${ }^{109}$ Third states like the USA and intergovernmental bureaucracies,

${ }^{106}$ The term honest broker originates in a speech of Otto von Bismarck at the Reichstag on 19 February 1878, in which he outlined Germany's position concerning the Oriental Question and his respective role during the Berlin Congress. Bismarck specified that it was not upon the German Reich (and him) to play the role of an arbitrator but rather one of an intermediary or mediator, of an honest broker in a transaction; see Various authors, 'Ehrlicher Makler', in Meyers Konversations-Lexikon (1885-1892), Vol V, at 349. Legend has it that Bismarck had been looking for three days for the right explanation and expression of his role. The Reichstag's protocols took note of "Heiterkeit"- "amusement"-in the auditorium as a response. Quoted in 'Ich fahre Europa vierelang', DIE ZEIT, 9 June 1978, <http://www.zeit.de/1978/24/ich-fahre-europa-vierelang> [last accessed 13 August 2012]. For a broad historical perspective on the development of mediation, see G. Althoff (ed), Frieden Stiften, Vermittlung und Konfliktlösung vom Mittelalter bis heute (Wissenschaftliche Buchgesellschaft, 2011).

${ }^{107}$ M. W. Reisman, 'Stopping Wars and Making Peace: Reflections on the Ideology and Practice of Conflict Termination in Contemporary World Politics', (1998) 6 Tulane Journal of International and Comparative Law 5, at 6; Kleffner, supra note 14, para. 12.

${ }^{108}$ E. N. Luttwak, 'Give War a Chance', (1999) 78 Foreign Affairs 36.

${ }^{109}$ Whether they criticise this practice of external involvement or welcome it, authors will 
most prominently the UN, whose declared purpose is to stop war and achieve peace, manifest this development ${ }^{110}$ To pursue their goals they actively address violent inter- and intra-state conflicts and work towards their termination and the establishment of sustainable peace processes ${ }^{111}$ Thus, third party mediation is increasingly brought to the parties of a conflict and does not necessarily wait for their invitation. Hence, mediation becomes pro-active often before some or all of the parties are in fact ready to sit down at the negotiation table $\mathrm{12}^{112}$ This essentially changes the character of mediation processes, as they obtain an interventionist character and take the form of externally led standard-stetting and norm-promotion processes $1{ }^{13}$ This in turn has a decisive effect on the role of mediators and their teams: they become active parties in negotiation processes as representatives of institutions and normative frameworks. The new mediators or peacemakers are not only able to set incentives but also to threaten the parties with sanctions or the use of force in the processes. They draft peace agreements and even constitutions and set incentives for the parties to enter them, and they even frame and make decisions in the event the parties are unable to do so. Furthermore, the performance of the mediator is dependent on a mandate that is often not granted by the parties to the conflict but mostly defined by a third party, a state or international organisation.

mostly agree that this development is rooted in a heightened interest in inter- and intra-state conflicts that often goes hand in hand with public pressure to end them through third party involvement. This is tied to a changing perception of conflict and peace (war and peace) in which what is perceived as an international community is concerned by war and its atrocities, be it an inter- or an intra-state war. It becomes impermissible not to take a position towards an ongoing conflict or to ignore it. See inter alia: Luttwak, ibid. On peacemaking as an " authoritative multilateral international transaction", see Reisman, supra note 107, 6 et seq. See also Kleffner, supra note 14, para. 7.

${ }^{110}$ International organisations have significantly contributed to the development of the practice of mediation. See amongst others Orrego Vicuña, supra note 12, para. 31 et seq.; Reisman, supra note 107, at 9; and Kleffner, supra note 14, para. 5.

111 Reisman, supra note 107 , at 9.

112 Reisman, supra note 107, at 6; and Kleffner, supra note 14, para. 12.

${ }^{113}$ It seems questionable, however, whether mediation ever had an entirely neutral character and that mediators performed their office without having recourse to power or force to coerce parties to peace. See Althoff, supra note 106, at 11-2 (Introduction by the editor). 


\section{A Professional Code of Conduct For Mediation and Peacemaking?}

Could mediation and peacemaking follow certain professional guidelines or ethical codes of conduct?

Classical mediation (mostly between private parties) is a defined profession, most visibly in North America, but increasingly in other parts of the world as well. The codes of conduct of these mediators are created domestically and usually include a set of ethical guidelines and specific training requirements. ${ }^{114}$ However, no group of peace mediators has emerged to create a global coalition that agrees on either a code of conduct or a common set of guidelines for the diverse actors involved in mediation processes in inter- and intra-state conflicts. ${ }^{115}$ Mediators in peace processes usually claim interpretative freedom for their activities and also to be able to act in the often-necessary secrecy. Additionally, the mediator often combines social, legal and political approaches to lead the parties to the settlement of a dispute. In this process mediators will sometimes override rules and standards of these sub-systems 117

There is, however, a growing number of handbooks and manuals for the peacemaker, some of them even taking the character of guidebooks on "how to make peace". In October 2006 for instance, the UN Peacemaker database was launched, a project of the United Nations Department for Political Affairs. The database is an Internet-based platform that is designed to support all kinds of peacemaking "professionals" to perform in a professional manner. It is supposed to function as a tool for the exchange of information and knowledge concerning peace processes and offers, for example, a glossary, a collection of peace agreements, case and best-practice studies as well as comments on peace agreements and on the management of peace processes ${ }^{118}$

114 Althoff, supra note 106, at 9.

115 Herrberg, supra note 18 , at 21.

116 Miller speaks about "The dark side of mediation". Referring to social theory he concludes: "Mediators, in short, need not to be all that honest, in fact probably cannot be all that honest and be successful; they might in some of their avatars be talebearers and spies. The historical record is so dense with examples of the dark side of mediation that one need not look long to find examples. It is hardly shocking to discover that mediators had their own interest to advance, they could benefit by gaining honor as a peacemaker, as well as by arranging a settlement that weakened the disputants who were often also the mediators' competitors." Miller, supra note 12 , at 19.

117 See Althoff, supra note 106, at 9-10 (Introduction).

118 The UN Peacemaker, supra note 74 (access with registration only; currently more than 6000 persons registered). 
The UN Peacemaker database also defines who is a peacemaker ${ }^{119}$ and what is understood as mediation $\sqrt{120}$ it gives advice on how to build a negotiation team (including legal experts) ${ }^{121}$ and it promotes that peacemaking is bound by international law, which is also reflected in drafting examples and handbooks ${ }^{122}$

Around the same time, Humanitarian Dialogue (HD) commenced a report initiative to identify standards and operational principles for peace mediation $\sqrt{123}$ The report offers practical guidance for the development of professional good conduct in mediation and peace processes. It does not seek to give precise guidance for specific situations but offers a frame of reference to support professional decision-making. It holds that a mediator has to be acceptable to all parties and not imposed upon any of them and that this impartial mediator must act in the best interests of the peace process ${ }^{124}$ Moreover, the mediator must assume ultimate accountability for his or her choices, actions and decisions throughout a peace process and may even decide to withdraw from a peace process when negotiations are obviously pursued in bad faith or are leading to a solution that is unworkable, illegal or profoundly at odds with the mediator's core values ${ }^{125}$ These guidelines seem to be addressed to a particular kind of mediator, i.e. members of NGOs or so-called private diplomacy institutions that are playing an increasingly important role. Hence, this could be considered as a first attempt at self-regulation of these institutions ${ }^{126}$

119 Definition: "A skilful Peacemaker can help open the path to dialogue, facilitate discussions, suggest solutions and help promote implementation. In choosing the Peacemaker, the following consideration may be required: His or her capacity to bring either a particular form of leverage to a situation or a specific skill to the process... If the Peacemaker is recognised as an individual with high moral or professional standing and as someone who can maintain his or her objectivity and impartiality, then from the onset, he or she will have the gravitas to be respected by the parties." The UN Peacemaker, Ibid.

${ }^{120}$ Ibid.

${ }^{121}$ Ibid.

122 The UN Peacemaker's Legal Library provides access to the fundamental legal instruments that guide international peacemaking efforts, The UN Peacemaker, Ibid.

123 'A Guide to Mediation, Enabling Peace Processes in Violent Conflicts', Centre for Humanitarian Dialogue (2007), i, available at <http://www.hdcentre.org/files/singapore_med_guide_LO.pdf $>$ [last accessed 5 February 2013].

124 Ibid., ii, at 18.

${ }^{125}$ Ibid.

${ }^{126}$ Smaller countries that have specialised in mediation, such as the Scandinavian countries and Switzerland, have become more risk-averse about engaging with armed groups, and certain types of diplomacy are thus becoming privatised. See also 'Privatising peace, Governments are increasingly handing over the early stages of conflict resolution to independent organisations', The Economist, 30 June 2011, <http://www.economist.com/node/18895458> [last accessed 13 August 2012]. 
Private diplomacy and mediation institutions represent private organisations and people, including former heads of states or governments and leading civil society representatives. Private diplomacy and mediation has become a crowded field, and the biggest players are, amongst others, the Crisis Management Initiative (CMI) founded by Martti Ahtisaari ${ }^{127}$ the Carter Centre's Conflict Resolution Programme, of former President Jimmy Carter ${ }^{128}$ and HD, which was established by Martin Griffiths ${ }^{129}$ a British diplomat and former UN Assistant Secretary-General. Thus, experienced mediators are starting to build their own offices, organisations and networks. These institutions and people complement traditional diplomacy, usually considered to be the domain of states as well as international organisations. They vary in their capacity, professionalism and size. Most of them can be characterised as international, non-profit organisations and a majority functions as associations or as registered foundations and some even as companies. Only a few are state-initiated institutions or religious organisations ${ }^{130}$ Based on this development, the literature offers a distinction between track two and track one mediation efforts. In short, while track one is considered as the mediation process between the conflict parties with the support of states and international organisations, track two negotiations and mediation processes include civil society movements and other groups and are mostly led by non-governmental private diplomacy and mediation institutions. Considering the activities of Ahtisaari and Carter, for instance, this distinction seems convenient but rather artificial, as they are active as mediators, or initiate mediation, on both tracks at the same or different time(s) ${ }^{131}$ In general, there is the tendency to engage different forms of mediation and types of mediators depending on the point in time of the transition from conflict to peace ${ }^{132}$

\footnotetext{
${ }^{127}$ See <http://www.cmi.fi/> [last accessed 13 August 2012]. See also Bell, supra note 75, at 74 et seq.

${ }^{128}$ See <http://www.cartercenter.org/peace/conflict_resolution/index.html> [last accessed 13 August 2012].

${ }^{129}$ See <http://www.hdcentre.org/> [last accessed 13 August 2012].

${ }^{130}$ A. Herrberg and H. Kumpulainen (eds), "The Private Diplomacy Survey 2008, Mapping 14 Private Diplomacy Actors in Europe and America', Crisis Management Initiative, November 2008, at 4 et seq, available at <http://www.initiativeforpeacebuilding.eu/pdf/IfP_mediation_mapping_the_private_diplomacy_survey.pdf> [last accessed 5 February 2013.

${ }^{131}$ See Bell, supra note 75 , at 74 et seq.

${ }^{132}$ See E. M. Cousens, 'It ain't over 'til it's over: what role for mediation in post-agreement contexts?' Centre for Humanitarian Dialogue, OSLO forum 2008-The OSLO forum Network of Mediators, available at <http://www.hdcentre.org > [last accessed 5 February 2013].
} 
In conclusion, it is possible to discern the development of a differentiated and professional peace service landscape, which goes hand in hand with the outsourcing of some aspects of mediation by states and international organisations and the growth of a competing private diplomacy and mediation "industry". The impact of this on the future development of the role of individual mediators and institutionalised mediation processes remains to be seen.

\section{Conclusion and Outlook}

By taking US Special Envoy Richard Holbrooke and the negotiation of the Dayton Peace Agreement as a key example, this article has described and analysed the role of a mysterious superhero peacemaker in a mediation and lawmaking process. This served as a basis for comparison with the role of the UN SG in mediation processes, in particular that of his Special Envoy Martti Ahtisaari in the Kosovo status negotiations. It revealed that mediators are more than mere facilitators of a negotiation process.

The role of the mediator in contemporary peace processes often goes beyond facilitating a dialogue-on invitation-between belligerent parties. Mediation is rather more often pro-active, with the mediator actively shaping the procedural and substantive aspects of negotiations by designing, offering or even dictating frameworks and solutions to the parties. Based on their mandate, professional expertise and a developing code of conduct, mediators become active part(ies) in negotiation processes and often take up the role of standard setters and norm promoters. Mediators can decisively influence the parties' decisionmaking by setting goals and using incentives or the threat of sanctions, or even the threat of the use of force, to push the parties to a solution. In this context, (international) law sets the limits and the framework for mediation and negotiation processes. The individual mediator becomes the bridge between these constraints and the necessity of addressing a particular conflict and mediating particular party-interests. Then law serves as a tool or technique for mediators/peacemakers to code the deal between the parties to the conflict.

Thus, the office of the mediator may be constrained by a mandate, external standards and structures, but it is then translated into practice by the individual mediator's skills in balancing and melding these with the status quo ante on the ground. In this setting, the individual mediator creates, and can even actively take part in, peace and lawmaking processes and thus, the development of (international) law. Admittedly, it remains difficult to decode and de-mystify 


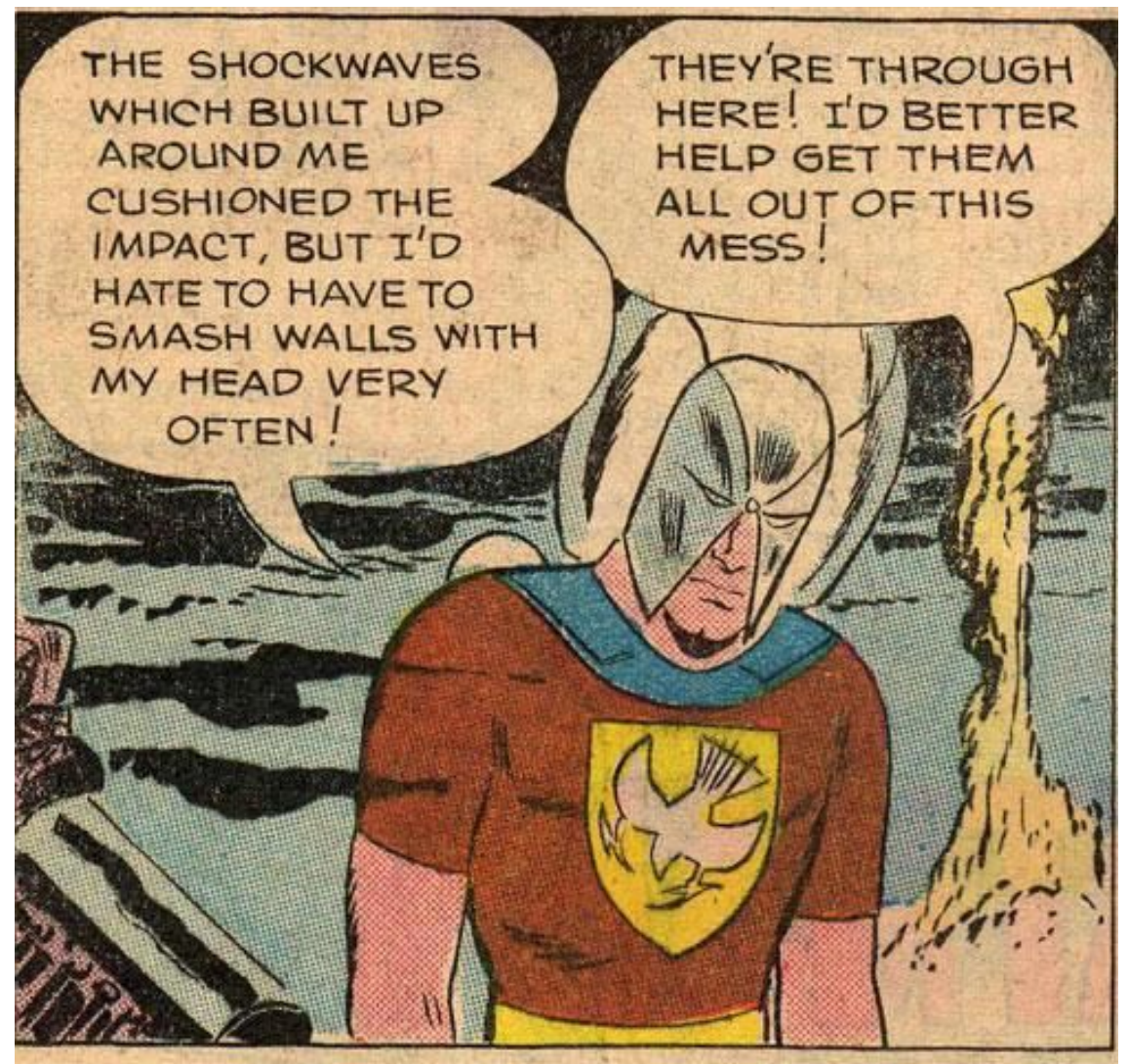

Figure 3: The Peacemaker, No. 4, Sept. 1967. @DC Comics.

the role of the (charismatic) individual mediator and to grasp clear causal relations between, and legal effects of, mediation and the actual role of the mediator in peace and lawmaking processes. In the end, however, the analysis of the role of mediators is an illustrative example of the undeniable but complicated role of the individual in the making of peace and (international) law. 